\title{
Effectiveness of Interspecific Hybridization for Incorporating Birch Leafminer (Fenusa pusilla) Resistance into White-barked Betula
}

\author{
William A. Hoch ${ }^{1}$ \\ Department of Horticulture, University of Wisconsin-Madison, Madison, WI 53706 \\ Geunhwa Jung ${ }^{2}$ \\ Department of Plant Pathology, University of Wisconsin-Madison, Madison, WI 53706 \\ Brent H. McCown ${ }^{3}$ \\ Department of Horticulture, University of Wisconsin-Madison, Madison, WI 53706
}

\begin{abstract}
AdDITIONAl INDEX wORDs. Betula spp., interspecific hybridization, Agrilus anxius, gene dosage, larval antibiosis, insect resistance, polyploidy, tree breeding

Abstract. A significant pest affecting commonly planted Betula spp. is the birch leafminer (Fenusa pusilla Lepeletier), an insect that can be present in large populations in the landscape and can greatly reduce the vigor and ornamental value of these trees. Twenty-two interspecific crosses were performed between leafminer resistant and susceptible Betula species in an attempt to create the novel combination of ornamental white bark and significant leafminer resistance. Of the nine successful crosses, two produced resistant offspring. Progeny of the diploid $\mathrm{x}$ hexaploid cross $\boldsymbol{B}$. turkestanica Litvin (2x) x B. alleghaniensis Britt. (6x) displayed a broad range of resistance levels, likely the result of segregating alleles contributed by the hexaploid parent. All crosses involving highly resistant individuals of $B$. costata Trautv. (2x) yielded leafminer susceptible progeny. These results suggest that the larval antibiosis demonstrated by $B$. alleghaniensis and $B$. costata is inherited as a recessive trait, and exhibits a gene dosage effect as evidenced by the $B$. turkestanica $\mathbf{x} B$. alleghaniensis offspring. While most progeny of the $B$. populifolia Marsh $(2 \times) \times B$. maximowicziana $\operatorname{Regal}(2 \mathrm{x})$ cross were susceptible, a single resistant offspring, which was found to be triploid (3x), displayed a mechanism of resistance similar to that of a hypersensitive response. No strong intersectional barriers to hybridization were observed and all interploidy crosses were successful. The chromosome numbers of $B$. costata $(2 \mathrm{n}=2 \mathrm{x}=28)$ and $B$. turkestanica $(2 \mathrm{n}=2 \mathrm{x}=\mathbf{2 8})$ are reported here for the first time. The results of this study indicate that the potential exists for the development of insect resistant, ornamental white-barked birch clones through the implementation of a planned, systematic breeding program.
\end{abstract}

White-barked birches (Betula spp.) continue to be widely utilized in both urban and rural settings despite serious insect pests that often limit their effective use. A significant pest affecting birches is the birch leafminer (Fenusa pusilla Lepeletier), an insect that can be present in large populations in the landscape. High densities of birch leafminer can greatly reduce the vigor and value of birch species commonly used for ornamental purposes since none are resistant to $F$. pusilla. Consequently, large amounts of insecticide are applied annually in attempts to control this insect. The development of ornamental white-barked birch clones that are highly resistant to birch leafminer would result in reduced labor, lower insecticide usage, reduced mortality, and greater landscape value.

Introduced into North America from Europe early in the $20^{\text {th }}$ century (Friend, 1933), the birch leafminer rapidly became a significant pest of Betula species planted in the United States and Canada. The birch leafminer is particularly problematic in land-

Received for publication 15 Feb. 2001. Accepted for publication 23 July 2002. The authors express their sincere appreciation to Elizabeth Scheef for assistance with the RAPD analysis, Robert Stupar for help with the chromosome counting, and Edward Bingham, Department of Agronomy, University of WisconsinMadison and Ray Guries, Department of Forest Ecology and Management, University of Wisconsin-Madison for reviewing the manuscript. The Horticultural Research Institute, the International Society of Arboriculture, the Wisconsin Arborists Association, Wisconsin Nurserymen's Association and the University of Wisconsin-Madison Agricultural Experiment Station generously supported this project.

${ }^{1}$ Graduate research assistant.

${ }^{2}$ Assistant professor.

${ }^{3}$ Gottschalk distinguished professor. scape settings (Jones and Raske, 1976) where it can mine virtually every leaf on a tree, causing considerable stress in late spring when tree energy reserves are at their lowest.

Adult birch leafminers oviposit exclusively into new expanding foliage. Upon hatching, the larvae consume the palisade and spongy mesophyll layers of the leaves during the first four instars of larval development (DeClerck and Shorthouse, 1985). The fifth instar exits the leaf and returns to the soil where a protective pupal chamber is constructed. Depending on length of the growing season and weather, two to four generations per year of $F$. pusilla will develop, with each generation lasting five to six weeks. As a result, leafminers are able to exploit new growth throughout the growing season, making it difficult for heavily infested birches to recover from the initial loss of early-season foliage.

The introduction and establishment of natural enemies of $F$. pusilla in North America has proven to be difficult (Van Driesche et al., 1997; Fuester et al., 1984; Langor et al., 2000). At present the most reliable means of controlling this insect in the landscape is through the use of systemic insecticides, either applied to the foliage or injected into the soil.

Although birch species resistant to $F$. pusilla have been identified (Hoch et al., 2000), it is apparent that no appreciable resistance exists in any species possessing bright-white bark. The use of interspecific hybridization could potentially incorporate leafminer resistance into the desirable white-barked phenotypes. Between 1995 and 2000, 22 different interspecific crosses were made between white-barked and leafminer resistant birch species, and the progeny tested for resistance to $F$. pusilla. 
Table 1. Results of Betula interspecific crosses: $\mathrm{S}$ = successful, hybrid progeny were obtained; $\mathrm{U}=$ unsuccessful, no hybrid progeny were obtained. Each cross was performed twice in different years.

\begin{tabular}{|c|c|c|c|c|c|c|c|c|c|c|c|}
\hline & & \multicolumn{10}{|c|}{ Male parent ${ }^{\mathrm{z}}$ (ploidy) } \\
\hline \multicolumn{2}{|c|}{ Female parent ${ }^{\mathrm{z}}$} & $\begin{array}{c}\text { Acuminatae }^{\mathrm{y}} \\
\max . \\
(2 \mathrm{x})\end{array}$ & all. & $\cos$. & erm. & len. & nig. & pap. & pla. & pop. & tur. \\
\hline Acuminatae & $\max .(2 \mathrm{x})$ & & & & & & & & & $\mathrm{U}$ & $\mathrm{U}$ \\
\hline \multirow[t]{3}{*}{ Costatae } & all. $(6 x)$ & & & & & & & & & & \\
\hline & $\cos .(2 x)$ & $S$ & & & $S$ & $\mathrm{U}$ & $\mathrm{U}$ & S & & $\mathrm{U}$ & $\mathrm{S}$ \\
\hline & nig. $(2 x)$ & $\mathrm{U}$ & & $\mathrm{U}$ & & & & & & & \\
\hline \multirow[t]{4}{*}{ Excelsae } & pap. $(6 x)$ & & & & & & & & & & \\
\hline & pla. $(2 x)$ & & & & & $\mathrm{U}$ & & & & & \\
\hline & pop. $(2 \mathrm{x})$ & $S$ & & & & $\mathrm{U}$ & & & & & \\
\hline & tur. $(2 x)$ & $S$ & $\mathrm{~S}$ & $\mathrm{~S}$ & $\mathrm{~S}$ & $\mathrm{U}$ & & & & & \\
\hline
\end{tabular}

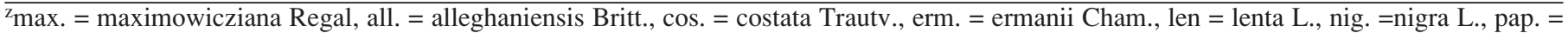
papyrifera Marsh, pla. = platyphylla Suk., pop. = populifolia Marsh, tur. = turkestanica Litvin.

ySeries listed by Krüssmann (1984).

Our results indicate the leafminer antibiosis expressed by $B$. alleghaniensis and $B$. costata is inherited in a recessive manner and is additive. This appears to be the first record of a gene dosage effect in a recessive antibiotic trait in crop plants.

\section{Materials and Methods}

Plant material. Interspecific crosses were performed at Longenecker Gardens in the University of Wisconsin-Madison Arboretum using trees ranging in age from 12 to 43 years. The accession numbers of these plants are listed parenthetically with the species names below. All plants were of wild-collected origin to minimize the chance of mixed or misidentified species being used in breeding. Species used in hybridization represented taxa from three different sections within Betula (Acuminatae, Costatae and Excelsae) and three different ploidy levels (Table 1).

Hybridization. Parental species used in breeding were selected based on their potential to contribute either white bark or leafminer resistance. Previous work (Hoch et al., 2000) detailed the resistance/susceptibility of the parental species. The leafminer susceptible white-barked species used for breeding were $B$. ermanii Cham. (92145), B. maximowicziana Regal (78006), B. papyrifera Marsh (69005), B. platyphylla Suk. (83209, 95007), B. populifolia Marsh (73032) and B. turkestanica Litvin (81207). An indication of possible leafminer resistance in the whitebarked species $B$. maximowicziana and B. ermanii (Fiori and Craig, 1987) prompted a limited number of crosses between these and other susceptible white-barked species listed above. Betula alleghaniensis Britt. (52001), B. lenta L. (60001) and selected individuals of $B$. costata Trautv. (91177), found to be highly resistant to $F$. pusilla, were utilized as the resistant breeding parents in most crosses.

To ensure an adequate number of female flowers, branches were selected when female catkins had begun to emerge but were not yet receptive to pollen. All male catkins were removed and the branches bagged with pollinating bags (\#404; Lawson Industries, Northfield, Ill.) to exclude unwanted pollen. To obtain pollen, branches with male catkins were cut from selected parent trees and placed into Erlenmeyer flasks containing tap water in the laboratory. Pollen was collected daily as the catkins dehisced by shaking the pollen onto a folded paper, which was then funneled into 1.5-mL microcentrifuge tubes. Pollen was tested on germination medium (Goldy and Lyrene, 1983) before pollination to ensure a reasonable level of viability. Pollen germination generally ranged from $20 \%$ to $80 \%$, and rarely did pollen have to be discarded due to low viability. Pollination was performed using a camelhair brush to transfer pollen onto the female catkins. Each pollination was performed three to four times per branch over the period of stigma receptivity. Pollinating bags were removed when the female catkins were no longer receptive $(\approx 2$ weeks). Seed strobiles were collected as they began to dry in late summer and early autumn, dried, and refrigerated in an airtight container. Two different plants per species were used for each cross, and all crosses were repeated in separate years to reduce the effects of environment on hybridization success.

Soon after harvesting, hybrid seeds were sown in flats filled with soilless potting medium (Scotts-Sierra Horticultural Products, Marysville, Ohio) and placed in a greenhouse to germinate. Seedlings were transplanted into individual $460-\mathrm{mL}(6 \times 6 \times 12.7$ $\mathrm{cm}$ ) pots (Anderson Die and Manufacturing, Portland, Ore.) as they reached suitable size. A number of open-pollinated seeds collected from each parent tree were started along with the hybrid seed to provide same-age references when identifying hybrid progeny.

Identification of hybrid offspring was accomplished using a combination of morphological characters, randomly amplified polymorphic DNA (RAPD) markers and chromosome counts. Populations were first screened for potential hybrids using morphological traits. The open-pollinated seedlings proved useful in identifying and comparing morphological characters contributed by the male parent species. In the occurrence of interploidy crosses, several hybrid offspring were selected from each cross and the chromosome numbers counted to help confirm the hybrid nature of these progeny. RAPD analysis was used in four crosses involving $B$. lenta; the reciprocal crosses with the morphologically similar $B$. costata, and crosses with $B$. platyphylla and $B$. turkestanica, which yielded several plants that appeared to be potential hybrids.

RAPD ANALYSIS. Genomic DNA was extracted from fresh, partially expanded leaves $(0.5$ to $0.75 \mathrm{~g}$ ) of individual field-grown 
or greenhouse-grown plants. Leaves were macerated in $450 \mathrm{~mL}$ of potassium ethyl xanthogenate (PEX) DNA extraction buffer in 2.0-mL microcentrifuge tubes with a ceramic bead using a FastPrep FP120 machine from BIO 101 Inc. (Carlsbad, Calif.) (Scheef et al., 2002). The rest of the DNA extraction procedure followed Johns et al. (1997) with minor modification.

Reactions for RAPD analysis were performed in 10-mL volumes in 96-well plates in an MJ PTC-100 (MJ Research, Watertown, Mass.) following the PCR profile of Johns et al. (1997). An arbitrary set of 20 RAPD primers (Operon Technologies, Alameda, Calif.) were initially screened with five subsamples. Twelve primers (AE4, AE6, AF6, AG14, C13, G19, K8, K8, K12, $\mathrm{K} 15, \mathrm{M} 14$, and P8) were selected for this study because of the consistent clarity and reproducibility of polymorphic bands and polymorphisms among samples tested. All RAPD reaction products were electrophoresed on $1.5 \%$ TBE/agarose gels as described by Johns et al. (1997). Gels were run for $1 \mathrm{~h} 40 \mathrm{~min}$ at 300 $\mathrm{V}$, stained with ethidium bromide, illuminated by UV light and photographed. Since RAPD markers segregate in a dominant pattern, we could determine whether the hybrids are derived from the intended parents if all amplified bands in the hybrids were also present in at least one of the parents.

Chromosome counting. Plants used for chromosome counts were established and grown in vitro as described by McCown (1989). In vitro root tips were harvested and prepared as described by Cheng et al. (2001), except that a 24-h ice-water pretreatment was used in place of the 2-h 8-hydroxyquinoline pretreatment. Chromosomes were viewed under $1200 \times$ magnification and images captured using a SenSys charge-coupled device camera (Photometrics), using IPLab Spectrum software (Signal Analytics). A minimum of six nuclei with clear chromosome separation were counted for each plant to determine chromosome number accurately.

LEAF MORPHOLOGICAL ANALYSIS. Leaf morphological characters were measured using 12 spur leaves per individual as described by Sharik and Barnes (1971). Leaf traits analyzed were petiole length, petiole length to blade length ratio and blade width to blade length ratio.

LEAFMINER RESISTANCE ASSAYS. Leafminers used in this study were reared in the laboratory and used in resistance assays as described by Hoch et al. (2000). Leafminer resistance assays were first performed on each hybrid while individually potted. Hybrid populations in which resistant individuals were identified were planted in the field test plot at the University of Wisconsin WestMadison Agricultural Research Station. Several individuals from each hybrid population consisting of all leafminer susceptible progeny were also planted in the field test plot.

Two separate resistance-rating schemes were used. Most progeny were assayed using a system where susceptible plants were those in which most larvae were able to molt to the fifth instar and drop from the leaf, while resistant plants were those in which the eggs did not hatch or the larvae died within the leaf. The variable resistance within the $B$. turkestanica $\times$ B. alleghaniensis population dictated that a more precise rating system be used. This second method graded the diameter of larval mines into five categories based on the final diameter of mines in the leaves: $\leq 1$ $\mathrm{mm},>1$ to $\leq 2 \mathrm{~mm},>2$ to $\leq 3 \mathrm{~mm},>3$ to $\leq 4 \mathrm{~mm}$, and $>4 \mathrm{~mm}$. Use of the mine diameter categories identified a threshold at $3 \mathrm{~mm}$ mine diameter that provided a clear separation between individuals that are susceptible (majority of mines $>3 \mathrm{~mm}$ diameter) and resistant (majority of mines $<3 \mathrm{~mm}$ diameter) (Hoch et al., 2000). Data presented for the B. turkestanica $\times$ B. alleghaniensis hybrids

Table 2. Methods used to determine interspecific Betula hybrid cross success.

\begin{tabular}{|c|c|c|c|c|}
\hline $\begin{array}{l}\text { Interspecific } \\
\text { hybrid } \\
\text { cross }^{z}\end{array}$ & $\begin{array}{l}\text { Hybrid } \\
\text { plants } \\
\text { (no.) }\end{array}$ & $\begin{array}{l}\text { RAPD } \\
\text { analysis }\end{array}$ & $\begin{array}{c}\text { Chromosome } \\
\text { no. }\end{array}$ & $\begin{array}{l}\text { Morphological } \\
\text { traits } \\
\text { used }\end{array}$ \\
\hline B. costata Trautv. $\times$ B. ermanii Cham. & 23 & & $\mathrm{X}^{\mathrm{y}}$ & Leaf shape and plicate texture \\
\hline B. costata $\times$ B. lenta $\mathrm{L}$ & 0 & $\mathrm{X}$ & & New shoot color, pubescence \\
\hline B. costata $\times$ B. maximowicziana Regal & 11 & & & Leaf pubescence, size, shape \\
\hline B. costata $\times$ B. nigra $\mathrm{L}$ & 0 & & & Leaf shape, number of vein pairs \\
\hline B. costata $\times$ B. turkestanica Litvin. & 40 & & & Leaf shape, number of vein pairs \\
\hline B. lenta $\times$ B. costata & 0 & $\mathrm{X}$ & & New shoot color, pubescence \\
\hline B. lenta $\times$ B. maximowicziana & 0 & & & Leaf pubescence, size, shape \\
\hline B. lenta $\times$ B. populifolia & 0 & & & Leaf shape, number of vein pairs \\
\hline B. maximowicziana $\times$ B. populifolia & 0 & & & No seedlings produced \\
\hline B. maximowicziana $\times$ B. turkestanica & 0 & & & No seedlings produced \\
\hline B. populifolia $\times$ B. maximowicziana & 620 & & & Leaf pubescence, size, shape \\
\hline B. turkestanica $\times$ B. alleghaniensis Britt. & 97 & & $\mathrm{X}$ & Leaf shape, presence of methyl salicylate \\
\hline B. turkestanica $\times$ B. costata & 59 & & & Leaf shape, number of vein pairs \\
\hline B. turkestanica $\times$ B. ermanii & 48 & & $X$ & Leaf shape and plicate texture \\
\hline B. turkestanica $\times$ B. lenta & 0 & $\mathrm{X}$ & & Leaf shape, number of vein pairs \\
\hline B. turkestanica $\times$ B. maximowicziana & 214 & & & Leaf pubescence, size, shape \\
\hline
\end{tabular}

${ }_{\mathrm{z}_{\text {max }} .}=$ maximowicziana Regal, all. = alleghaniensis Britt., cos. = costata Trautv., erm. = ermanii Cham., len $=$ lenta L., nig. $=$ nigra L., pap. $=$ papyrifera Marsh, pla. = platyphylla Suk., pop. = populifolia Marsh, tur. = turkestanica Litvin.

${ }^{\mathrm{y}} \mathrm{X}$ indicates the analysis was performed. 


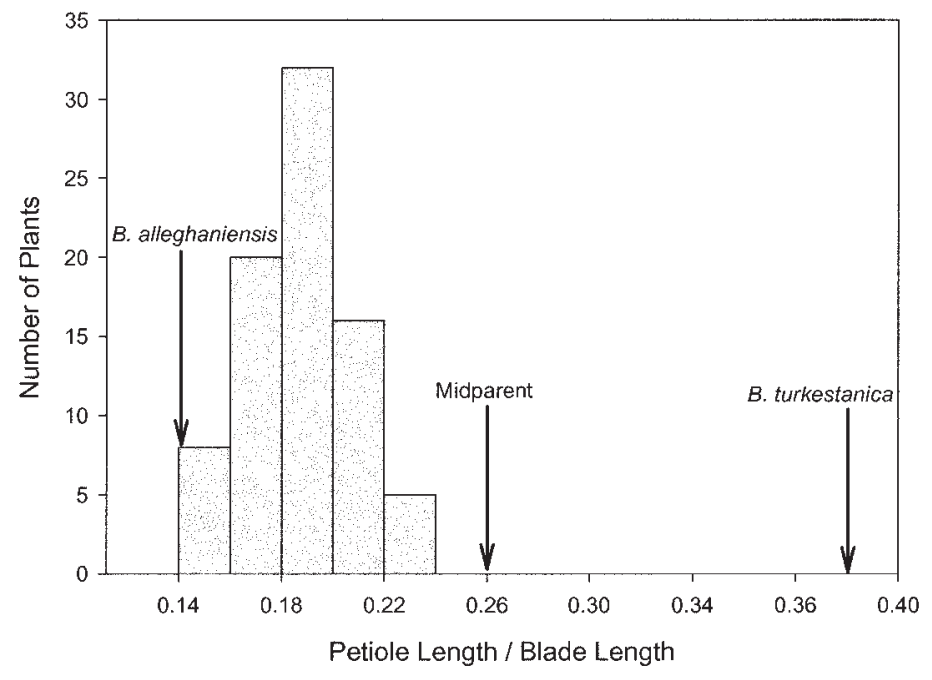

Fig. 1. Frequency distribution of a Betula turkestanica Litvin $\times$ B. alleghaniensis Britt. $F_{1}$ population by petiole length/blade length ratio (Data are from a population resulting from a single cross between two individuals, $\mathrm{n}=81$ ).

are taken from a population resulting from a single cross between two individuals. This particular cross produced a large number of hybrid offspring as a result of an increased number of branches pollinated in 1996 following the discovery of a number of resistant progeny in the 1995 crosses. Hybrid progeny from other individual pairings of this cross displayed a similar distribution of resistance levels. Data from the largest population only are presented to exhibit the full range of phenotypes resulting from a single cross. Mine size data represents all mines totaled over three assays per individual performed during the 1999 growing season when the plants were three years of age $(n=81)$.

\section{Results and Discussion}

Hybridization. Hybrid progeny were obtained from nine of the 22 interspecific hybrid crosses performed (Table 1). Hybrid progeny were obtained in both years for all successful crosses, while no offspring were obtained in either year for all unsuccessful crosses. Despite careful bagging and pollen-handling procedures, all attempted crosses (with the exception of the two crosses involving $B$. maximowicziana as the female parent, which produced no seedlings) yielded a number of nonhybrid offspring. Williams et al. (1999) identified several postpollination barriers to hybridization between the sympatric $B$. occidentalis and $B$. papyrifera. These barriers gave conspecific pollen major advantages over interspecific pollen, greatly reducing the number of interspecific hybrids obtained from controlled crosses. Barriers such as these could well explain the occurrence of nonhybrid progeny in our crosses. Undesired pollen apparently fertilized a number of ovules despite the seemingly overwhelming amount of interspecific pollen applied to the stigmas. This undesired pollen probably contacted the stigmas during the short period of time when the bags were removed to facilitate hand pollination. Apomixis could also be an explanation for these nonhybrid progeny, however, these nonhybrid seedlings displayed considerable phenotypic variation, indicating these plants were sexually produced. Little or no indication of apomixis was observed during this study.

Two notable exceptions to the relatively low yield of hybrid seed were when $B$. maximowicziana served as the male parent in crosses with two section Excelsae species, B. populifolia and $B$. turkestanica. Both of these crosses produced a high proportion of both viable seed and hybrid seed, with the $B$. populifolia $\times B$. maximowicziana cross in particular yielding a very high percentage of hybrid seed (Table 2). Despite being intersectional, these crosses clearly possessed no barriers to hybridization.

No strong intersectional barriers to hybridization were observed, as at least one cross was successful between each of the three Betula sections utilized in this study; in addition, the two crosses between the sections Excelsae and Acuminatae were highly fertile. All interploidy crosses (diploid $x$ tetraploid and diploid $x$ hexaploid) were successful, indicating no significant interploidy barriers within Betula, at least when the higher ploidy species serves as the male parent.

Although B. maximowicziana served as a prolific male parent in several successful interspecific crosses, it produced no hybrid progeny when used as a female parent. However, several years of collecting open-pollinated seed from the B. maximowicziana plants used as female parents in this study failed to produce a single seedling. Therefore, the two crosses involving this native of northern Japan as the female parent may have failed not due to incompatibility barriers between the species, but possibly due to environmental or other factors that affected the viability of seed produced by these plants in our study. With the exception of two crosses involving B. maximowicziana, all other reciprocal crosses produced similar results regardless of the direction of the cross.

The combination of morphological characters, chromosome number and RAPD markers provided accurate and reliable identification of the hybrid offspring (Table 2). Hybrid progeny were easily identified morphologically in crosses where the parental species differed significantly in leaf characteristics. Examples of this include all crosses involving B. maximowicziana, which has a pubescent leaf that is much larger than any other Betula species, and most crosses between species of the section Excelsae and B. alleghaniensis, B. costata or B. lenta, as the later three species possess longer, narrower leaves with 10 to 14 pairs of veins vs the 5 to 8 vein pairs of the section Excelsae species.

RAPD markers were used when confirmation of potential hybrids was inconclusive using morphological traits. The 12 RAPD primers used produced numerous polymorphic bands that were usable in determining parentage. None of the plants analyzed using RAPD markers were found to be the offspring of the intended parents.

Wintergreen oil (methyl salicylate), an aromatic compound

Table 3. Results of leafminer resistance assays for progeny of successful interspecific hybrid crosses. (R) and (S) represent resistant and susceptible plants, respectively.

\begin{tabular}{|c|c|}
\hline Interspecific Betula hybrid cross & Results $^{z}$ \\
\hline B. costata $(\mathrm{R}) \times$ B. maximowicziana $(\mathrm{S})$ & Susceptible \\
\hline B. $\operatorname{costata}(\mathrm{R}) \times$ B. $\operatorname{ermanii}(\mathrm{S})$ & Susceptible \\
\hline B. costata $(\mathrm{R}) \times$ B. papyrifera $(\mathrm{S})$ & Susceptible \\
\hline B. $\operatorname{costata}(\mathrm{R}) \times$ B. turkestanica $(\mathrm{S})$ & Susceptible \\
\hline B. populifolia $(\mathrm{S}) \times$ B. maximowicziana $(\mathrm{S})$ & Susceptible ${ }^{y}$ \\
\hline B. turkestanica $(\mathrm{S}) \times$ B. maximowicziana $(\mathrm{S})$ & Susceptible \\
\hline B. turkestanica $(\mathrm{S}) \times$ B. alleghaniensis $(\mathrm{R})$ & Variable resistance ${ }^{x}$ \\
\hline B. turkestanica $(\mathrm{S}) \times$ B. costata $(\mathrm{R})$ & Susceptible \\
\hline B. turkestanica $(\mathrm{S}) \times$ B. ermanii $(\mathrm{S})$ & Susceptible \\
\hline
\end{tabular}

${ }^{\mathrm{z}}$ Susceptible is defined as most larvae were able to molt and drop from the leaf.

${ }^{y}$ One of the resulting progeny was resistant.

${ }^{x}$ Resistance ranged from the resistant to the susceptible parent, see Fig 1. 


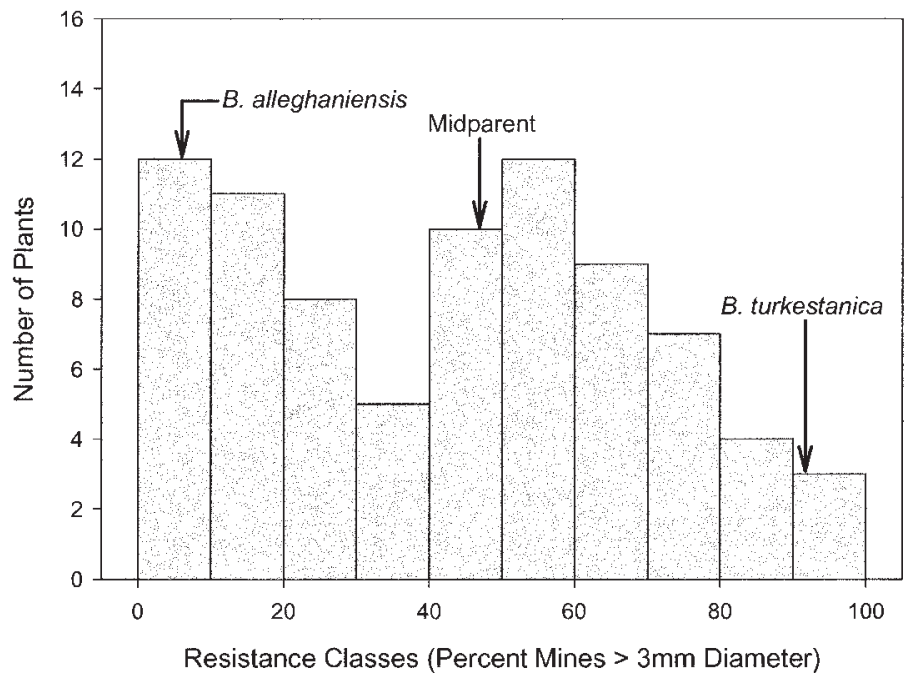

Fig. 2. Frequency distribution of Betula turkestanica Litvin $\times$ B. alleghaniensis Britt. $\mathrm{F}_{1}$ population by percent of $F$. pusilla mines $>3 \mathrm{~mm}$ diameter. A mine $>3$ mm diameter indicates a susceptible interaction. Resistance class values represent the percent of all mines totaled over three assays per individual during the 1999 growing season (Data is from a population resulting from a single cross between two individuals, $\mathrm{n}=81$ ).

produced in the underbark of all parts of $B$. alleghaniensis and $B$. lenta, and in the roots of $B$. costata, served as a reliable indicator of hybrid progeny in the $B$.turkestanica $\times$ B. alleghaniensis cross. In these hybrid offspring, the odor of methyl salicylate was detectable, but at a lower level than that found in B. alleghaniensis. This observation is consistent with the findings of Barnes et al. (1974) who found reduced levels of methyl salicylate in naturally occurring hybrids of $B$. alleghaniensis $\mathrm{x} B$. papyrifera.

The results of our interspecific crosses differ from those obtained by several previous studies in two important aspects. Smith and Nichols (1941), Johnsson (1945), Johnson and Heimburger (1946) and Clausen $(1966,1970)$ all report successful crosses between $B$. lenta and one or more white-barked species within the section Excelsae (B. platyphylla var. japonica, $B$. populifolia, B. papyrifera, and $B$. pubescens), and all but Johnsson (1945) indicate successfully producing interspecific hybrids between $B$. nigra and several of these same Excelsae species. However, these reports offer little or no evidence verifying hybridity and often presume interspecific hybrid success based simply on seedling production. Based on our study, it would appear improbable that B. lenta or B. nigra can be successfully hybridized to any white-barked Betula species.

Morphological CHARACTERS. The effect of gene dosage was evident in interploidy crosses, where the level of ploidy difference between the parents correlated to the amount of phenotypic similarity between the hybrid offspring and the higher-ploidy parent. For example, B.turkestanica $(2 \mathrm{x}) \times$ B. alleghaniensis $(6 \mathrm{x})$ progeny were similar to the hexaploid parent in almost all observable traits. The leaf morphological traits measured in this study have previously been shown in birch to be at the midparent value for intraploidy hybrids (Barnes et al., 1974) and significantly closer to the higherploidy parent in interploidy hybrids (Sharik and Barnes, 1971). In the case of $B$. turkestanica $\times$ B. alleghaniensis hybrid offspring, the ratio of petiole length/blade length (Fig. 1) was typical of the phenotypic similarity to the hexaploid parent displayed by all leaf morphological characters measured.

The chromosome numbers of $B$. costata $(2 \mathrm{n}=2 \mathrm{x}=28)$ and $B$. turkestanica $(2 \mathrm{n}=2 \mathrm{x}=28)$ were determined during this project and are reported here for the first time. The chromosome preparation technique described by Cheng et al. (2001), with our minor modification, provided consistent and reliable chromosome spreads.

LEAFMINER RESISTANCE. Leafminer resistance assays revealed that most interspecific crosses between leafminer resistant and susceptible parents produced offspring susceptible to $F$. pusilla (Table 3). All crosses involving B. costata produced susceptible progeny, despite the high level of leafminer resistance in the $B$. costata individuals utilized for breeding. These populations may prove important for future breeding, as the segregation of traits in the $\mathrm{F}_{2}$ generation would be expected to produce a number of resistant individuals.

A single leafminer resistant offspring was isolated from the $B$. populifolia $(2 \mathrm{x}) \times$ B. maximowicziana $(2 \mathrm{x})$ cross that otherwise produced many susceptible plants. The resistant plant was found to be triploid, likely the result of an unreduced gamete. This plant also displayed an unusual mechanism of resistance to $F$. pusilla, which resembled the programmed cell death associated with the hypersensitive response (Agrios, 1988). The resistance mechanism of this plant is unique among the species utilized in this study, and appears to be similar to that displayed by resistant individuals of $B$. davurica (Hoch et al., 2000). However, the bark color and vigor of this plant are unacceptable for commercial release, and the fact that it is triploid ( $3 \mathrm{x})$ suggests that it will be of little value to future breeding work.

The only hybrid population that exhibited resistance to $F$. pusilla was that of the $B$. turkestanica $\times$ B. alleghaniensis cross. These progeny displayed considerable variation in leafminer resistance, ranging from the resistant to the susceptible parent (Fig. 2). The diversity of leafminer resistance found within this population is distinctly different from most other traits observed. As described above, these offspring are phenotypically very close to $B$. alleghaniensis, however most plants possess resistance to $F$. pusilla that is intermediate between the parents, with some individuals displaying the leafminer susceptibility of $B$. turkestanica. The broad range of leafminer resistance levels in this population suggests the segregation of alleles responsible for resistance contributed by the hexaploid $B$. alleghaniensis. Segregation of other B. alleghaniensis traits was also observed. Clausen and Godman (1967) and Clausen (1973) describe bark characteristics in populations of $B$. alleghaniensis ranging from ambercolored smooth or peeling to dark and rough textured. They also noted a correlation between the bark type and growth rate, with the smooth or peeling barked trees exhibiting a 2- to 3-fold faster growth rate than those with dark, roughed textured bark. We observed a similar range of bark types in our B. turkestanica $\times$ B. alleghaniensis $\mathrm{F}_{1}$ population, which also strongly correlated to the differences in growth rates observed in these earlier studies. It is interesting that a seemingly full range of $B$. alleghaniensis bark types segregated out of a single $B$. alleghaniensis parent with peeling, amber-colored bark. Betulin, a triterpene responsible for the bright outer bark of white-barked Betula species, was not visible in any of the hybrid offspring, further demonstrating the phenotypic similarity of the progeny to the hexaploid parent.

Offspring of the $B$. turkestanica $\times$ B. alleghaniensis cross may prove useful in future breeding. Consistent homologous pairing during meiosis in hybrid birch originating from diploid $(2 \mathrm{x}) \mathrm{x}$ hexaploid (6x) crosses has been reported (Johnsson, 1949; written communication from Frank Santamour in Sharik and Barnes, 1971). This indicates that the B. turkestanica $\times$ B. alleghaniensis population may possess a suitable level of fertility from which the 
segregation of some traits, particularly traits of the diploid parent, would be expected.

The relatively low level of leafminer resistance found in the $B$. turkestanica $\times$ B.alleghaniensis population and the susceptibility of all progeny resulting from crosses involving highly resistant individuals of the diploid species, $B$. costata, suggests that resistance to $F$. pusilla in $B$. alleghaniensis and $B$. costata is inherited as a recessive trait. This trait also exhibits a gene dosage effect as evidenced by the $B$. turkestanica $\times$ B. alleghaniensis offspring, indicating that the resistance is additive. It was previously shown that the larval antibiosis of these two species, along with two other closely related taxa, $B$. lenta and B. grossa, are comparable (Hoch et al., 2000). The evidence presented here is consistent with an analogous or identical mechanism of leafminer resistance functioning in $B$. alleghaniensis and $B$. costata, and also suggests that the leafminer resistance of $B$. grossa and $B$. lenta would likely be inherited in a similar manner.

To our knowledge this is the first description of a gene-dosage effect in a recessive antibiotic trait. Differences in ploidy between the closely related taxa $B$. alleghaniensis and $B$. costata provided an opportunity to observe the expression of this trait under different dosage levels. However, the inheritance of resistance indicated by these data is preliminary, as data from the $\mathrm{F}_{2}$ generations will be required to characterize the inheritance of this trait.

Resistance to another important insect pest of birch trees, the bronze birch borer (Agrilus anxius Gory) has also been considered in our program. Several of the parental species utilized in our breeding project were chosen in part based on observed or potential resistance to the bronze birch borer (Santamour and Lundgren, 1997). However, significant breeding gains in bronze birch borer resistance will not be realized without an efficient resistance assay. A putative mechanism of resistance to $A$. anxius has been identified (Santamour, 1990) and may contribute to the development of an effective means of assaying for resistance. As indicated above, no hybrid progeny were obtained from crosses involving the river birch (B. nigra L.), a species well documented to be resistant to $A$. anxius (Santamour and Lundgren, 1997). These results are consistent with several other studies (reviewed by Santamour, 1999) indicating that it may be extremely difficult through breeding to incorporate the desirable traits of $B$. nigra with other important characteristics, including resistance to $F$. pusilla, within this genus.

Continued breeding will be required to significantly express the ornamental and insect resistance traits emphasized in this project. The $F_{1}$ hybrids have begun to reach flowering age and will be utilized in further breeding, which will be directed towards combining the aforementioned traits with other important characteristics, including growth rate, habit and urban tolerance. Determining the inheritance of traits such as bark characteristics and the observed insect resistance mechanisms are also important goals of our research.

\section{Literature Cited}

Agrios, G.N. 1988. Plant pathology. Academic Press, San Diego, Calif. Barnes, B.V., B.P. Dancik, and T.L. Sharik. 1974. Natural hybridization of yellow birch and paper birch. Forest Sci. 20:215-221.

Cheng, Z., R.M. Stupar, M. Gu, and J. Jiang. 2001. A tandemly repeated DNA sequence is associated with both knob-like heterochromatin and a highly decondensed structure in the meiotic pachytene chromosomes of rice. Chromosoma 10:24-31.

Clausen, K.E. 1966. Studies of compatibility in Betula. Joint Proc. $2^{\text {nd }}$ Genet. Wkshp. Soc. Amer. Foresters and Seventh Lake States Tree Improv. Conf., USDA For. Serv. Res. Paper NC-6.

Clausen, K.E. 1970. Interspecific crossability tests in Betula. Proc. IUFRO
Sect. 22 Working Group on Sexual Reproduction of Forest Trees, Meeting at Varparanta, Finland, May 1970.

Clausen, K.E. 1973. Genetics of yellow birch. USDA For. Serv. Res. Paper WO-18.

Clausen, K.E. and R.M. Godman. 1967. Selecting superior yellow birch trees-A preliminary guide. USDA For. Serv. Res. Paper NC20.

DeClerck, R.A. and J.D. Shorthouse. 1985. Tissue preference and damage by Fenusa pusilla and Messa nana (Hymenoptera: Tenthredinidae), leafmining sawflies on white birch (Betula papyrifera). Can. Entomol. 117:351-362.

Fiori, B.J. and D.W. Craig. 1987. Relationship between color intensity of leaf supernatants from resistant and susceptible birch trees and rate of oviposition by the birch leafminer (Hymenoptera: Tenthredinidae). J. Econ. Entomol. 80:1331-1333.

Friend, R.B. 1933. Birch leaf-mining sawfly, Fenusa pumila Klug. Conn. Agr. Expt. Sta. Bul. (NewHaven) 348:291-364.

Fuester, R.W., P.B. Taylor, W.H. Day, R.M. Hendrickson, and E.M. Blumenthal. 1984. Introduction of exotic parasites for biological control of the birch leafminer (Hymenoptera: Tenthredinidae) in the middle Atlantic states. J. Econ. Entomol. 77:1565-1570.

Goldy, R.G. and P.M. Lyrene. 1983. Pollen germination in interspecific Vaccinium hybrids. HortScience 18:54-55.

Hoch, W.A., E.L.Zeldin, and B.H. McCown. 2000. Resistance to the birch leafminer Fenusa pusilla Hymenoptera: Tenthredinidae) within the genus Betula. J. Econ. Entomol. 93:1810-1813.

Johns, M.A., P.W. Skroch, J. Nienhuis, P. Hinrichsen, G. Bascur, and C. Munoz-Schick. 1997. Gene pool classification of common bean landraces from Chile based on RAPD and morphological data. Crop Sci. 37:605613.

Johnson, L.P.V. and C. Heimburger. 1946. Preliminary report on interspecific hybridization in forest trees. Can. J. Res. (Sec. C) 24:308-312.

Johnsson, H. 1945. Interspecific hybridization within the genus Betula. Hereditas 31:163-176.

Johnsson, H. 1949. Studies of birch species hybrids. I. Betula verrucosa $\mathrm{X}$ $B$. japonica, $B$. verrucosa $\times$ B papyrifera and $B$. pubescens $\times B$. papyrifera. Hereditas 35:115-135.

Jones, J.M. and A.G. Raske. 1976. Notes on the biology of the birch leafminer, Fenusa pusilla (Lep.), in Newfoundland (Hymenoptera: Tenthredinidae). Phytoprotection 57:69-76.

Krüssmann, G. 1984. Manual of cultivated broad-leaved trees and shrubs. vol. 1. Timber Press, Beaverton, Ore.

Langor,D.W., S.C. Digweed, D.M. Williams, J.R. Spence, and C. Saunders. 2000. Establishment and spread of two introduced parasitoids (Ichneumonidae) of the birch leafminer, Fenusa pusilla (Lepeletier) (Tenthredinidae). Biocontrol 45:415-423.

McCown, B.H. 1989. Birch (Betula spp.). Biotechnology in agriculture and forestry. Trees. II. vol. 5. Springer-Verlag, Berlin.

Santamour, Jr., F.S. 1990. Rhododendrol and susceptibility to the bronze birch borer. J. Arboricult. 16:260-263.

Santamour, Jr., F.S. 1999. Progress in the development of borer-resistant white-barked birches. J. Arboricult. 25:151-162.

Santamour, Jr., F.S. and L.N. Lundgren. 1997. Rhododendrin in Betula: a reappraisal. Biochem. Syst. Ecol. 25:335-341.

Sharik, T.L. and B.V. Barnes. 1971. Hybridization in Betula alleghaniensis Britt. and B. lenta L.: A comparative analysis of controlled crosses. For. Sci. 17:415-424.

Scheef, E., M. Casler, and G. Jung. 2002. Development of species-specific SCAR markers in bentgrass. Crop Sci. (in press).

Smith, E.C. and C. Nichols, Jr. 1941. Species hybrids in forest trees. J. Anold Arbor. 22:443-454.

Van Driesche, R.G., R. Childs, R.A. Casagrande, and L. Tewksbury. 1997. Establishment, distribution and impact in southern New England of Lathrolestes nigricollis (Thompson)(Hymenoptera: Ichneumonidae), an introduced parasitoid of the birch leafminer, Fenusa pusilla (Lepeletier) (Hymenoptera: Tenthredinidae). Can. Entomol. 129:601-611.

Williams, Jr., J.H., W.E. Friedman, and M.L. Arnold. 1999. Developmental selection within the angiosperm style: Using gamete DNA to visualize interspecific pollen competition. Proc. Natl. Acad. Sci. USA 96:92019206. 